\title{
COMPARISON OF THE CARDIOVASCULAR AND RESPIRATORY EFFECTS OF LIGHT GENERAL ANAESTHESIA AND BRACHIAL PLEXUS BLOCK*
}

\author{
Wulliam F. Kennedy, JR., M.D., John J. Bonica, M.D., \\ ANDrew G. Tolas, D.D.S., Wayne E. Martin, M.D., \\ and Alexander Grinstein, M.D.†
}

For SEVERAL DECADEs there have been numerous discussions among anaesthesiologists concerning the most ideal anaesthetic for surgical procedures involving the upper extremity. Enthusiasts for regional anaesthesia have argued that, when properly performed, a brachial plexus block produces no unfavourable physiologic effects; others feel, however, that light general anaesthesia is preferable for surgery on the upper extremity. In an attempt to elucidate the problem, we compared the cardiovascular and respiratory changes during a brachial plexus block and a general anaesthetic in a series of subjects with each individual serving as his own control, i.e., a brachial plexus block was first performed and the cardiorespiratory changes noted; when the block had worn off completely, a general anaesthetic was administered.

\section{Methods and Materials}

Ten healthy adult male volunteers, aged 20 to 42 , were studied. The study was explained thoroughly to the subjects and a written consent obtained. All subjects were brought to the anaesthesia study room in a fasting and unmedicated state and, with the aid of local anaesthesia, teflon and vinyl catheters were inserted percutaneously into the brachial artery and superior vena cava, respectively. The catheters were connected to suitable transducers, and pressures were recorded continuously, as was the electrocardiogram. Cardiac output was determined with indocyanine green; the area under the dye curve was measured planimetrically. ${ }^{1}$ Arterial blood was sampled anaerobically, and $\mathrm{Po}_{2}$ and $\mathrm{pH}$ determined with a modified Clark electrode and an Astrup $\mathrm{pH}$ electrode respectively. The tonometric method of Astrup was used to calculate $\mathrm{Pa}_{\mathrm{CO}_{2}}$. Stroke volume was determined from cardiac output and cardiac rate. Total peripheral resistance was calculated by the following formula:

TPR units (dynes $\left./ \mathrm{sec} / \mathrm{cm}^{-5}\right)=\frac{\text { mean arterial blood pressure }(\mathrm{mm} \mathrm{Hg})}{\text { cardiac output }(\mathrm{ml} / \mathrm{sec})} \times 1332$

All measurements were made while the subject was supine.

'Supported by US Army Research and Development Command, Office of the Surgeon General, Contract DA 49-193-мD-2231.

tDoctors Kennedy, Bonica, and Martin are in the Department of Anesthesiology, University of Washington School of Medicine, Seattle, Washington. Dr. Tolas is in the Departments of Anesthesiology and Oral Surgery, University of Washington Schools of Medicine and Dentistry; and Dr. Grinstein is with the Cobb Medical Center, Seattle, Washington. 
After the subjects had rested for 30 minutes, control measurements were made. Then, according to the technique first described by Kulenkampff ${ }^{2}$ and modified by Bonica, ${ }^{3}$ a right supraclavicular brachial plexus block was performed with $30 \mathrm{ml}$ of 1.5 per cent lidocaine hydrochloride with epinephrine 1:200,000 $(150 \mu \mathrm{g})$. (Drugs and concentrations in current use were employed for both procedures to make the investigation more meaningful to the clinical anaesthesiologist.) The cardiovascular and blood gas measurements were repeated 5, 15 , and 30 minutes after the start of the brachial block and at subsequent 30 minute intervals until the anaesthetic had worn off.

Following another 30 minute rest period, control values were again recorded. General anaesthesia was then induced via a semiclosed circle absorption system. The subject breathed 100 per cent oxygen for three minutes and then a combination of nitrous oxide $(7 \mathrm{~L} / \mathrm{min})$ and oxygen $(3 \mathrm{~L} / \mathrm{min})$. Halothane was gradually introduced into the system from a previously calibrated Mark II Fluotec vaporizer until plane 1 of stage $\mathrm{m}$ anaesthesia was obtained. The anaesthetic was administered via an anaesthetic face mask; in some cases an oropharyngeal airway was used. None of the subjects were intubated and they all breathed spontaneously. Every 15 minutes a maximum inflatatory manoeuvre was performed. The electroencephalogram was monitored throughout general anaesthesia and, following induction, the patient was maintained between EEG level II and III as described by Gain and Paletz. ${ }^{*}$ Halothane concentration used for induction ranged from 3 to 4 per cent; the maintenance concentration of halothane ranged from 0.25 to 0.75 per cent. Cardiovascular and blood gas values were recorded $5,15,30,60$, and 90 minutes after induction. Administration of the general anaesthetic was then terminated, and 30 minutes later cardiovascular and blood gas values were recorded for the final time.

Cardiovascular and blood gas measurements were converted to per cent change from control values. The significance of the change was determined with the Student's $t$-test.

\section{RESULTS}

The results are summarized in Figures 1 to 9 .

\section{Mean arterial pressure (Fig. 1)}

Brachial plexus block initially increased mean arterial pressure 5 per cent. This was followed by a fall of 3 per cent and a gradual return to control levels $(p<0.05)$. General anaesthesia with halothane-nitrous oxide produced a profound and statistically significant $(p<0.01)$ drop in mean arterial pressure ( 20 to 30 per cent). Fifteen minutes following the general anaesthetic, the mean arterial pressure had returned to control. Differences between the two anaesthetics were significant.

\section{Cardiac rate (Fig. 2)}

Brachial plexus block increased cardiac rate 5 to 15 per cent for 60 minutes $(p<0.05$ to 0.01$)$. General anaesthesia with halothane-nitrous oxide initially increased cardiac rate 15 per cent $(p<0.01)$; it returned to control after 15 minutes. Fifteen minutes after the anaesthetic this parameter was 33 per cent 


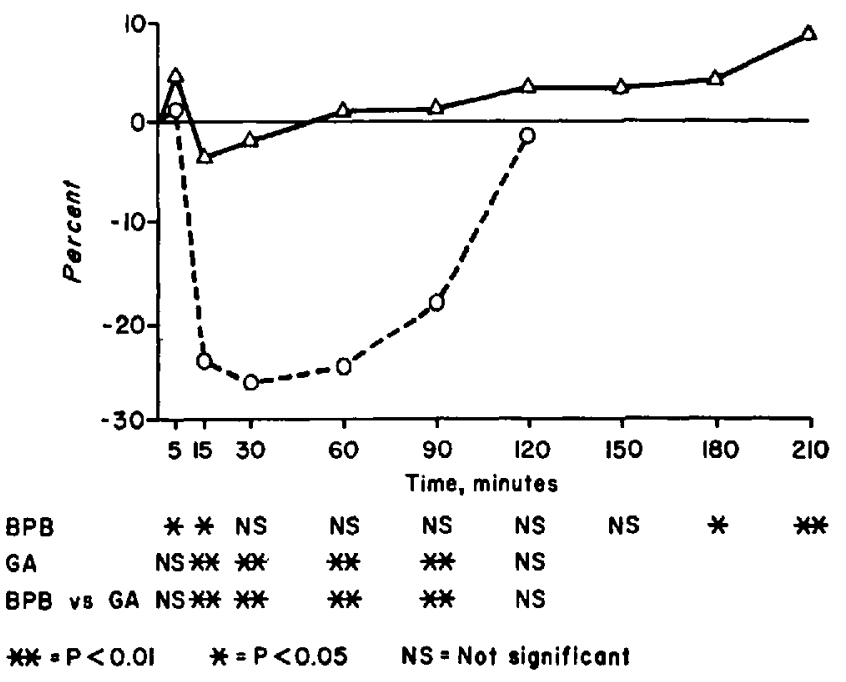

Figure 1. Mean per cent change in mean arterial pressure from mean control value, represented as zero, during brachial plexus block (BPB) $\triangle \longrightarrow \Delta$, and general anaesthesia (GA), O ---0 .

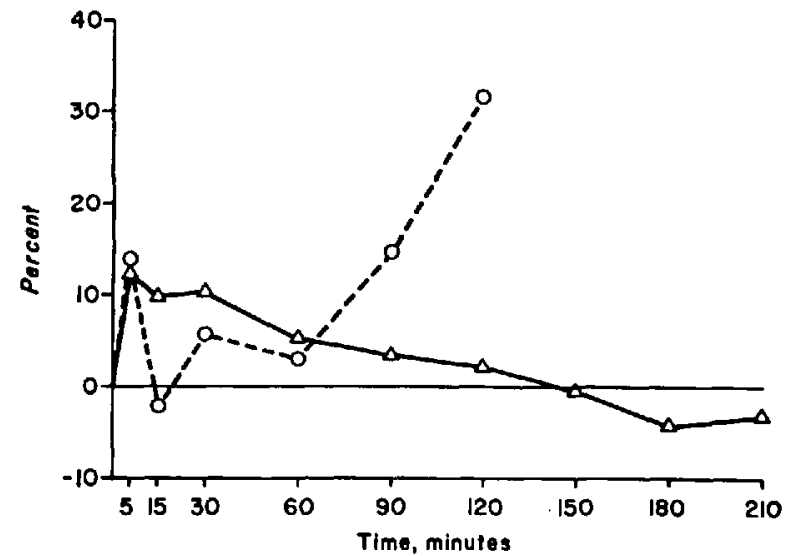

\begin{tabular}{|c|c|c|c|c|c|c|}
\hline BPB & $* * * * * *$ & * & NS & NS & NS & NS \\
\hline GA & *ANS NS & NS & * & $* *$ & & \\
\hline$B P B$ vB $G A$ & NS* NS & NS & NS & $* *$ & & \\
\hline
\end{tabular}

Figure 2. Mean per cent change in cardiac rate from mean control value, represented as zero. Symbols as in Figure 1.

above control. Brachial plexus block and general anaesthesia differed little as far as cardic rate was concerned.

Cardiac output (Fig. 3)

Brachial plexus block produced a profound and statistically significant increase ( 42 per cent) in cardiac output for 90 minutes $(p<0.01)$. Except for an initial 


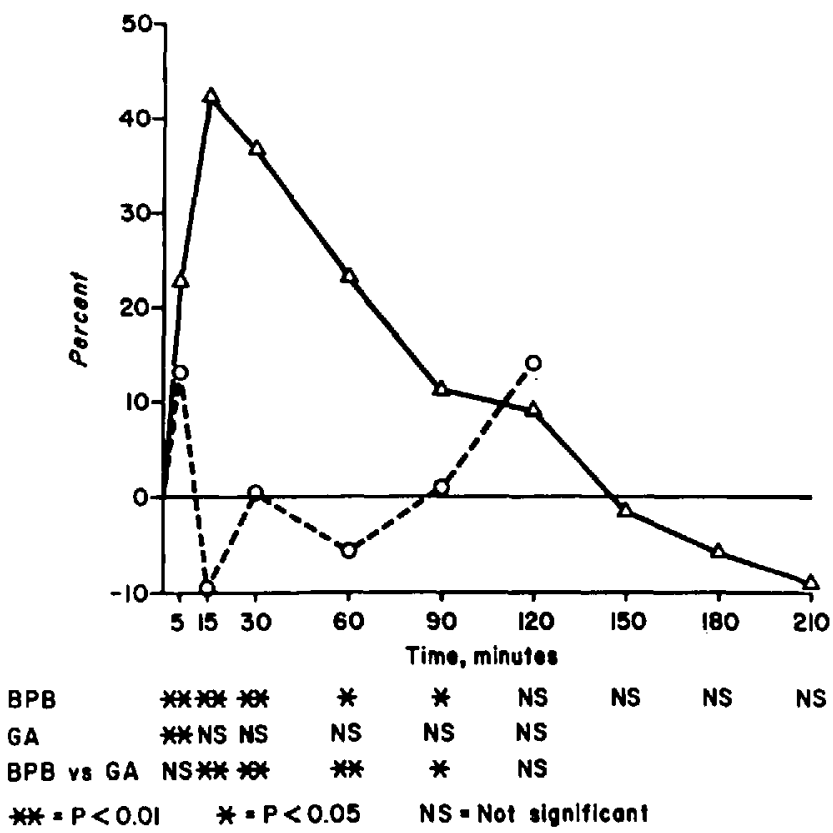

Figure 3. Mean per cent change in cardiac output from mean control value, represented as zero. Symbols as in Figure 1 .

increase of 12 per cent, cardiac output did not change greatly with general anaesthesia.

Stroke volume (Fig. 4)

During the regional anaesthesia, stroke volume increased as much as 30 per cent before returning to control at the 120 minute period, whereas, with halothane-nitrous oxide it decreased 5 to 7 per cent.

\section{Total peripheral resistance (Fig. 5)}

Brachial plexus block produced a 10 to 30 per cent decrease in calculated total peripheral resistance ( $p<0.05$ to 0.01 ). These effects persisted for 60 minutes before returning to control level. Halothane-nitrous oxide produced a 10 to 24 per cent fall which persisted throughout general anaesthesia.

\section{Central venous pressure (Fig. 6 )}

The central venous pressure increased during both anaesthetics but to a greater degree with the halothane-nitrous oxide anaesthetic.

\section{Blood gases (Figs. 7, 8, 9)}

The brachial block did not affect the blood gas levels. The general anaesthetic slightly increased $\mathrm{Pa}_{\mathrm{CO}_{2}}$ and slightly decreased $\mathrm{pH}$. As one would expect with administration of 30 per cent oxygen, the arterial oxygen tension was elevated. 


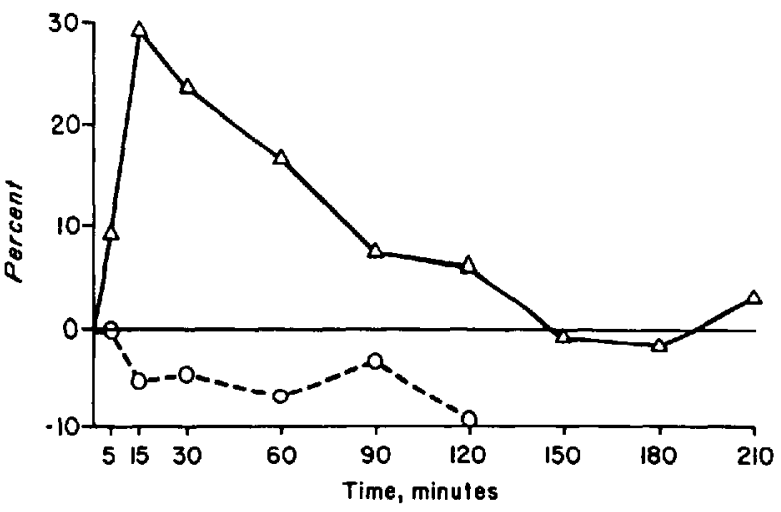

$\begin{array}{llllllll}\text { BPB } & \text { NS**** } & * & * & \text { NS } & \text { NS } & \text { NS } & \text { NS } \\ \text { GA } & \text { NSNS NS } & * & \text { NS } & \text { NS } & & & \\ \text { BPB } \text { yS GA } & \text { NS**** } & * * & \text { NS } & * & & \end{array}$

$* *=P<0.01 \quad *=P<0.05 \quad$ NS $=$ Not significant

Figure 4. Mean per cent change in stroke volume from mean control value, represented as zero. Symbols as in Figure 1.

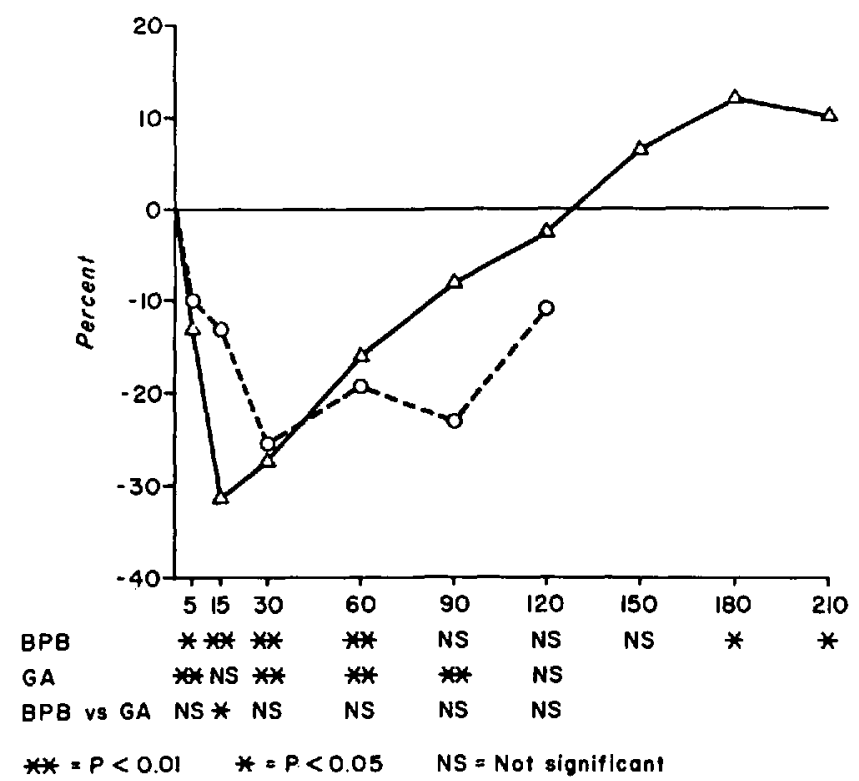

Figure 5. Mean per cent change in total peripheral resistance from mean control value, represented as zero. Symbols as in Figure 1. 


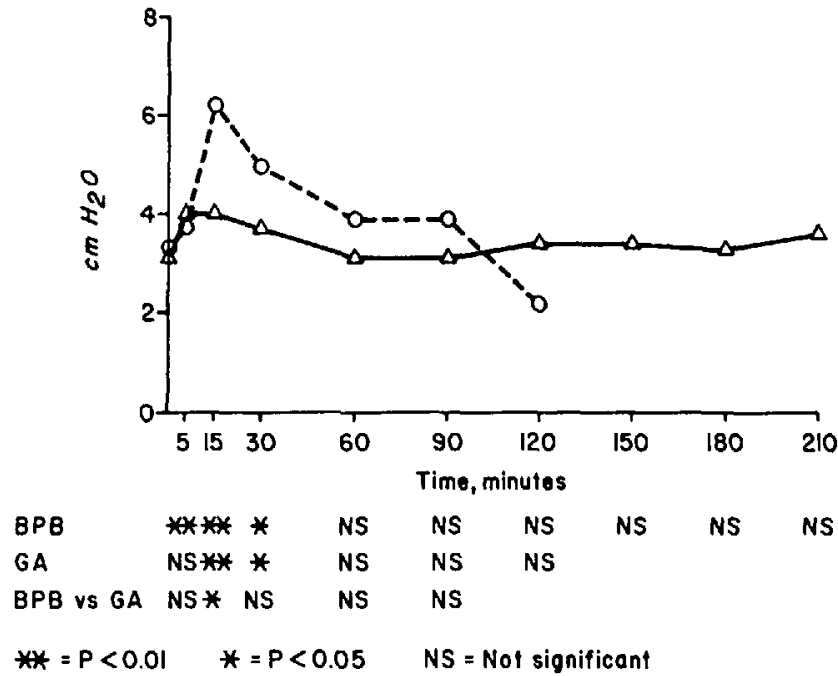

Figure 6. Variations in mean central venous pressure from mean control value. Symbols as in Figure 1.

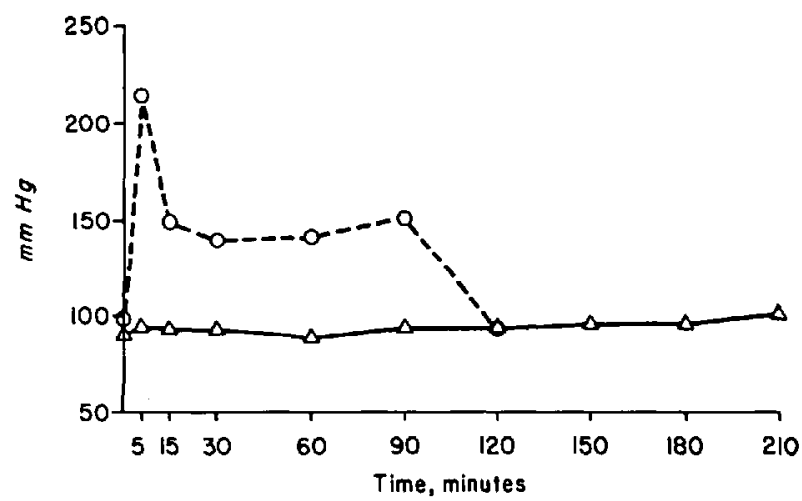

$\begin{array}{lllll}\text { BPB } & \text { NSNS NS } & \text { NS } & \text { NS } & \text { NS NS NS * } \\ \text { GA } & * * * * * * & * * & * * & \text { NS } \\ \text { BPB vS GA } & * * * * * & * * & * * & \text { NS } \\ * *=P<0.01 \quad * *=P<0.05 & \text { NS }=\text { Not significont }\end{array}$

FIGURE 7. Variations in mean arterial oxygen tension from mean control value. Symbols as in Figure 1. 


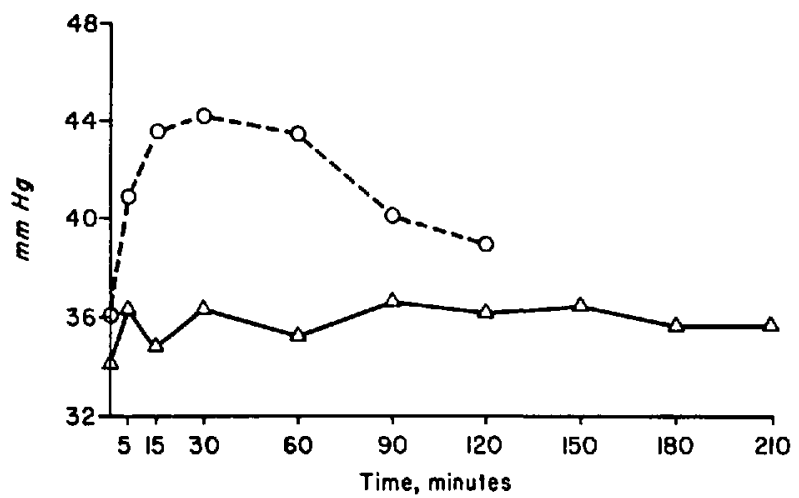

BPB *NS * NS NS NS NS NS NS

GA $\quad * * * *$ ** $* *$ NS NS

BPE vS GA NS*** * * NS NS

** $=P<0.01 \quad *=P<0.05 \quad N S=$ Not significant

Figure 8. Variations in mean arterial carbon dioxide tension from mean control value. Symbols as in Figure 1.

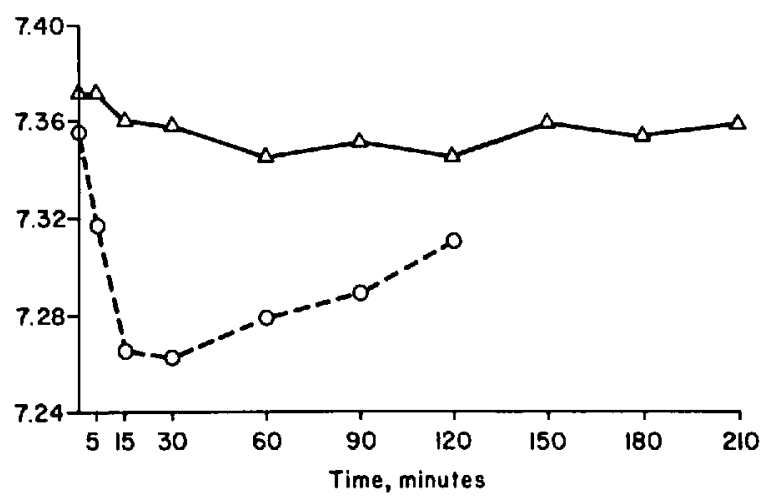

$\begin{array}{lllllll}\text { BPB } & \text { NS NS NS } & \text { NS } & \text { NS } & \text { NS } & \text { NS } & \text { NS } \\ \text { GA } & * * * * * & * * & * * & * * \\ \text { BPB ys GA } & \text { NS **** } & * * & * & \text { NS } \\ * *=P<0.01 & *=P<0.05 & N S=\text { Not significant }\end{array}$

Frgure 9. Variations in mean arterial pH from mean control value. Symbols as in Figure 1. 


\section{Discussion}

We have previously reported ${ }^{5}$ that when epinephrine is incorporated into local anaesthetic solution for certain regional anaesthetic procedures, sufficient epinephrine is absorbed into the systemic circulation to produce profound and statistically significant cardiovascular changes. These changes include increases in cardiac rate, cardiac output, and stroke volume, and decreases in mean arterial pressure and calculated total peripheral resistance. As Ahlquist ${ }^{6}$ first suggested, these changes represent the beta effects of epinephrine. The alpha response, vasoconstriction, is not seen with the amounts of epinephrine used for regional anaesthesias. The systemic cardiovascular effects observed in this study were a product of beta adrenergic receptor stimulation, and they persisted for 60 to 90 minutes.

With light halothane-nitrous-oxide anaesthesia (stage III, plane I, EEG levels II-III, inspired concentration of halothane $0.25-0.75$ per cent) mean arterial pressure and calculated total peripheral resistance exhibited significant decreases, but cardiac rate, cardiac output, and stroke volume changed only slightly. Mean $\mathrm{Pa}_{\mathrm{CO}_{2}}$ increased from 36 to $44 \mathrm{~mm} \mathrm{Hg}$. These cardiovascular and respiratory findings are similar to the changes observed by Deutsch et al. in their studies on normal human subjects. ${ }^{7}$

Brachial plexus block without epinephrine incorporated into the local anaesthetic solution does not produce significant cardiovascular or respiratory changes. ${ }^{5}$ Nonetheless, as epinephrine increases the duration of anaesthesia and lowers the blood levels of local anaesthetic, it is definitely indicated in regional anaesthetics. Such changes observed during brachial plexus block done with 30 $\mathrm{ml}$ of 1.5 per cent lidocaine hydrochloride with epinephrine 1:200,000 are probably not of clinical significance. General anaesthesia with halothane-nitrous oxide has a small but significant depressant action on the cardiovascular and respiratory systems. Although these changes produced by the general anaesthetic are probably not significant in normal individuals, they could, in some circumstances, assume clinical significance. In view of its lesser unfavourable cardiovascular and respiratory effects, brachial plexus block, when properly performed, would appear to be preferable to light general anaesthesia for surgery of the upper extremity.

\section{SUMMARY}

Brachial plexus block with epinephrine $(1: 200,000)$ and general anaesthesia with halothane-nitrous oxide-oxygen in the same individual were compared. The brachial plexus block with epinephrine produced statistically significant changes in cardiac rate, cardiac output, stroke volume, and calculated total peripheral resistance. These effects were due to the epinephrine incorporated in the local anaesthetic solution. General anaesthesia with halothane-nitrous oxide produced significant decrease in the mean arterial pressure and total peripheral resistance. On the basis of cardiovascular and respiratory effects, brachial plexus block is considered to be preferable for surgery of the upper extremity. 


\section{RÉSUMÉ}

Les effets cardiovasculaires et respiratoires du bloc brachial ont été comparés avec les effets de l'anesthésie générale chez dix volontaires de sexe masculin en bonne santé. Chaque sujet servait à son propre contrôle. On a pratiqué les examens cardiovasculaires et sanguins suivants: la pression artérielle moyenne et le rythme cardiaque d'après la pression artérielle continue et les données de l'ECG; le débit cardiaque par la technique de dilution; le calcul du volume systolique et de la résistance périphérique totale; la pression veineuse centrale; les tensions d'O $\mathrm{O}_{2}$ et de $\mathrm{CO}_{2}$ artériels et le $\mathrm{pH}$. Durant le bloc brachial il y a eu augmentation importante du rythme cardiaque, du débit cardiaque, du volume systolique, et une diminution importante de la résistance périphérique, le tout attribué à l'effet béta de l'épinéphrine dans l'anesthésique local. Sous anesthésie générale, la pression artérielle moyenne et la résistance périphérique totale ont subi une baisse sensible. Etant donné ses effets cardiovasculaires et respiratoires moins nocifs, le bloc brachial bien fait semblerait préférable à une anesthésie générale légère pour les interventions sur les membres supérieurs.

\section{REFERENCES}

1. Grassch, P. J. \& WARD, R. J. Two Graphical Methods for Determination of Dilutioncurve Area. J. Lab. Clin. Med. 66: 830 (1965).

2. KulenkampfF, D. \& Persky, M. A. Brachial Plexus Anaesthesia: Its Indications, Technique, and Dangers. Ann. Surg. 87: 883 (1928).

3. Bonica, J. J. The Management of Pain. Philadelphia: Lea and Febiger (1953).

4. Gain, E. A. \& Paletz, S. G. An Attempt to Correlate the Clinical Signs of Fluothane Anaesthesia with the Electroencephalographic Levels. Canad. Anaesth. Soc. J. 4: 289 (1957).

5. Kennedy, W. F., Jr; Bonica, J. J.; Ward, R. J.; Tolas, A. G.; Martin, W. E.; \& GrinSTEIN, A. Cardiorespiratory Effects of Epinephrine when Used in Regional Anaesthesia. Acta anaesth. scandinav. Suppl. XXIII: 320 (1966).

6. AHLQuist, R. P. A Study of Adrenotropic Receptors. Am. J. Physiol. 153: 586 (1948).

7. Deutsch, S.; Linde, H. W.; Dripps, R. D.; \& Price, H. L. Circulatory and Respiratory Actions of Halothane in Normal Man. Anesthesiology. 23: 631 (1962). 